\title{
Mycoviruses - the potential use in biological plant protection
}

\section{Mykowirusy - perspektywy wykorzystania w biologicznej ochronie roślin}

\author{
Marcin Łaskarzewski ${ }^{1 *}$, Jolanta Kiełpińska² ${ }^{2}$ Kinga Mazurkiewicz-Zapałowicz ${ }^{3}$
}

\section{Summary}

Biological plant protection is an alternative mean to the chemical pesticides used on a large scale, the use of which carries a great danger for the functioning of living organisms, including humans. Many mycoviruses, which are able to interfere with the host's phenotypic image, have shown great potential in the control of phytopathogenic fungi. The symptoms are composed of the phenomenon of hypovirulence, i.e. the reduction of fungal pathogenicity in relation to the plant. There are known mycoviruses capable of infecting the most important phytopathogens, including Magnaporthe oryzae, Botrytis cinerea, Fusarium graminearum or Rhizoctonia solani. This is the basis for continuing research to develop effective antifungal agents.

Key words: phytopathogenic fungi, mycovirus, biological control of crop, fungal diseases, hypovirulence

\section{Streszczenie}

Biologiczna ochrona roślin stanowi alternatywę dla wykorzystywanych na masową skalę związków chemicznych, których stosowanie niesie ze sobą duże niebezpieczeństwo dla funkcjonowania organizmów żywych, w tym człowieka. Ogromny potencjał w walce z grzybami fitopatogennymi kryje się w mykowirusach, które są zdolne do ingerowania w obraz fenotypowy gospodarza, ograniczając między innymi tempo wzrostu grzybni, zdolność sporulacji czy wywołując efekt cytolityczny. Powyższe objawy składają się na zjawisko hipowirulencji, czyli obniżenia patogenności grzyba w stosunku do rośliny. Poznane zostały mykowirusy zdolne do infekowania najistotniejszych fitopatogenów, w tym Magnaporthe oryzae, Botrytis cinerea, Fusarium graminearum czy Rhizoctonia solani. Stanowi to podstawę do kontynuacji badań, służących opracowywaniu skutecznych preparatów przeciwgrzybiczych.

Słowa kluczowe: grzyby fitopatogenne, mykowirus, biologiczna ochrona roślin, grzybicze choroby roślin, hypowirulencja

\footnotetext{
Zachodniopomorski Uniwersytet Technologiczny w Szczecinie

${ }^{1}$ Wydział Nauk o Żywności i Rybactwa

${ }^{2}$ Wydział Nauk o Żywności i Rybactwa, Zakład Gospodarki Rybackiej i Ochrony Wód

${ }^{3}$ Wydział Nauk o Żywności i Rybactwa, Katedra Hydrobiologii, Ichtiologii i Biotechnologii Rozrodu

Kazimierza Królewicza 4, 71-550 Szczecin

*corresponding author: marcinlaskarzewski@wp.pl
} 


\section{Wstęp / Introduction}

Fungi are living organisms whose earliest fossils date back to about 460 million years (Redecker et al. 2000), and molecular clock studies suggest an even older metric of more than one billion years (Parfrey et al. 2011). This indicates that fungi have appeared on Earth earlier than land plants (the oldest plant fossils are about 420 million years old), and some scientists even suggest that they have allowed colonization of the Earth by the first plants (Redecker et al. 2000).

First scientific observations and experiments with fungi, including their germination, are attributed to the Italian scientist Pietro Antonio Micheli, who was named the father of mycology. In 1729 he published a book describing about 1900 species of organisms, 900 of which belonged to fungi. As the precursor of modern mycology, German Anton Antoine de Bary is recognized as the first to prove that fungi are etiological factors of plant diseases, which has been the impetus for the development of phytopathology. Since then until now, knowledge about fungi has developed very dynamically, new species are being discovered as well as remarkable interactions between fungi and other organisms. The aspect of cross-species interactions with fungi is especially gaining increasing interest in practical use in medicine, economy and agriculture. These studies seem to have an indefinite time perspective, because at present there are at least 99000 species of fungi and FLOs (fungi-like organisms) on our planet, and new taxa (about 1200 per year) are also being rapidly discovered (Kirk et al. 2008; Blackwell 2011; Carris et al. 2012). This fact makes it prudent to estimate that the total number of fungal species on Earth is approximately 1500000 (Hawksworth 2001). This impressive number contains a great variety of heterotrophic organisms representing fungi and fungal-like organisms, now called mycobiote. The unlimited adaptability of mycobiote resulting from their morphology, anatomy, and exceptional physiology provided them with evolutionary success and made them possible to be considered as cosmopolitan and ubiquitous organisms. In all natural ecosystems and agroecosystems, their interaction with plants is of particular importance. Most plant-related mycobiote are saprotrophs, causing their debris to decompose, which they use as a source of nutrients (Carris et al. 2012). Less than $10 \%$ of mycobiote species are capable of colonizing living plants (Knogge 1996) and among these groups are distinguished species that occur with symbiosis (endo- or ectomycorrhizal) plants and parasitic mycobiota (pathogens) (Carris et al. 2012). Phytopathogenic mycobiote utilizes nutrients taken from a living host plant, resulting in disease progression in the plant and leading to its death. According to bibliographic data up to now, more than 8000 species of mycobiotes have been found to be phytopathogenic (Ellis et al. 2008). There are also known pathogenic fungi (Pier et al. 2000), inducing insect zoomycosis (entomopathogens) (Meyling and Eilenberg 2007) and vertebrate dermatoses, including human being (Deangelis et al. 2005).

Phytopathogenic fungi, by their effect on the health, quality and quantity of crop yields, have always played an important role in the food economy. It is estimated that up to $70 \%$ of plant diseases are caused by phytopathogenic fungi (Carris et al. 2012). Integrated plant protection methods commonly used in various plant cultivation mostly limits these losses. However, there are known in history catastrophic examples of the epidemic occurrences of plant diseases that have affected the lives of millions of people. For instance, the Great Famine in Ireland was a period of mass starvation and disease (1845-1850), when Phytophthora infestans, which caused potato blight, infected up to one-half of the potato crop in 1845, and about three-quarters of the crop over the next seven years (Clark 2010). The Potato Famine resulted in the death of about 1.5 million and the mass emigration of an equally large group to the United States. Another example is the epidemic of powdery mildew of vine, caused by FLO Plasmopara viticola. In the second half of the 19th century, $P$. viticola infected vineyards in western and central Europe, causing huge losses in the vineyards and in consequence, a decline in wine production (Ellis et al. 2008). In the 20th century, a number of leaf blight epidemics were recorded, resulting in huge crop and financial losses. It is worth mentioning Puccinia graminis f. sp. tritici crop infections resulting in the destruction of more than 10 million $\mathrm{m}^{3}$ of wheat in the United States and Canada and in 1953-1954 only in US causes a loss about \$ 365 million (USDA 2017). A list of the 10 most important phytopathogens causing global economic losses has been developed (Dean et al. 2012). This list includes, in order: (1) Magnaporthe oryzae, (2) Botrytis cinerea - the cause of gray mold, (3) Puccinia spp. - causes of rust, especially cereal crops, (4) Fusarium graminearum - the cause of cereal fusariosis, (5) Fusarium oxysporum - the cause of plant tracheomicosis, (6) Blumeria graminis - the cause of powdery mildew, (7) Mycosphaerella graminicola - the cause of striped septoriosis of wheat leaves, (8) Colletotrichum spp. - cause of antracnosis of various plants, (9) Ustilago maydis - the root cause of maize, (10) Melampsora line - the cause of flax rust. In addition, two phytopathogens were identified: Phakopsora pachyrhizi and Rhizoctonia solani, which caused respectively soy rust and rhizoctoniosis of various plant seedlings and potato rhizoctoniosis.

The quality of crop plants after harvest is strongly connected with the presence and biochemical activity of phytopathogens producing toxic compounds. Many mycotoxin-producing fungi are common, and often very strongly related to plants, and consequently also to food production. The natural fouling by fungi of the food industry is dominated by three genera: Aspergillus, Fusarium and 
Penicillium. Fusarium species are developing pathogens on cereals and other crops, producing mycotoxins during vegetation or just after harvest. The majority of Aspergillus and Penicillium species, which are also pathogens or plant commensals, are commonly grown on plant products during their drying and storage (Pitt 2000), leading to contamination with mycotoxins. As a result of human or animal consumption of plant products contaminated with mycotoxins, mycotoxicosis may be affected, a toxic effect manifesting as deterioration in health (Peraica et al. 1999).

The negative effects of the influence of mycobiotes on the quantity and quality of plant production are forcing them to seek new methods of preventing them. Therefore, the purpose of this paper is to review the literature on the assessment of the potential and effectiveness of mycoviruses as fungistatic or fungicidal agents in biological protection of plants.

\section{Aktualnie stosowane metody przeciwdziałania i zwalczania grzybów fitopatogennych oraz wpływ tych metod na inne organizmy / Currently applied methods of countering and control phytopathogenic fungi and the influence of these methods on other organisms}

The occurrence of plant epiphytoses is associated with economic and often sociological consequences such as diseases, famine and population migration. Because of that plant protection with a number of preventive and intervention methods is needed. The most effective preventive methods to eliminate or reduce the presence of phytopathogens in ecosystems are strategies related to (1) good agricultural practice, based on high agrotechnical culture, (2) use of genetically modified plants for resistance to phytopathogenic growth, (3) breeding of resistant varieties and (4) external and internal quarantine regulations (Ellis et al. 2008). Interventions are the ability to control phytopathogens with (5) the use of chemicals and (6) biological methods. Possibilities of using genetically resistant cultivars/varieties (3) provide a defense against viral, bacterial, and fungal infections. The necessary condition for registration of new potato varieties is, among others, their resistance to Synchytrium endobioticum - the cause of potato canker, a disease that occurred in the first half of the 20th century, and currently has no significant significance. Cultivars resistant to $P$. infestans have been developed to limit the occurrence of the potato late blight. There are known soy cultivars resistant to Peronospora manshurica, causing agent of powdery mildew, and various cereal resistant varieties resistant to B. graminis (formerly Erysiphe graminis), an etiological agent of powdery mildew of cereals and grasses (Ellis et al. 2008). Of course, this resistance is not a lasting feature due to the emerging pathotypes of pathogens. The loss of such resistance were reported by the breeders of wheat cultivars resistant to $P$. graminis f. sp. tritici when a new strain of $P$. graminis f. sp. tritici - Ug99 (in the US nomenclature known as TTKSK) was introduced in Uganda with a potential mutation causing the development of rust on a resistant wheat variety. It has been found that this pathogen rapidly mutated and as many as 13 strains of this phytopathogen within the Ug99 line have been identified as early as 2016, capable of growing on resistant varieties of wheat, which is a real threat to the crop worldwide (Singh et al. 2011; Patpour et al. 2016).

Prevention and intervention methods related to the use (5) of chemicals are based on: (a) the use of soil fumigants, (b) the application of fungicides during vegetation, and (c) the use of fungicides after the harvest of plant crops.

Unfortunately, the use of chemical plant protection products, including fungicides, presents a great danger to the functioning of living organisms, from microorganisms through plants and animals, to humans. Due to excessive application of fungicides in the vine protection, wine yeast inhibition (Calhelha et al. 2006) and photosynthesis in vines have been observed (Saladin et al. 2003; Petit et al. 2008). In relation to mammals, researchers found problems with sexual differentiation and reproduction in mice (Gray et al. 1994; Paro et al. 2012), as well as a number of dysfunctions in humans, like neurological diseases, hypospadias, endocrine disorders and increased incidence of cancer (Saracci et al. 1991; Blair et al. 1993; Kamel and Hoppin 2004). Fungicides and their metabolites enter the body through the skin (USEPA 1992), and may accumulate in fat, liver, thyroid and nervous system (Kamrin 1997). Farmers and others working in plantations where pesticides are used are considered the hazardous group (Saracci et al. 1991; Blair et al. 1993; Garry et al. 2002).

Another undesirable consequence of the use of chemical plant protection products is the production of resistant phytopathogenic pathotypes, which is associated with reduced efficiency and the need to use still new chemical groups. The above problems led scientists to intensify their work on biological plant protection methods which involves maximizing the use of natural processes and dependencies in biocenosis while maintaining homeostasis of the agroecosystem (Campbell 1989).

Algae (Kulik 1995), bacteria including cyanobacteria and actinomycetes (Kulik 1995; Walsh et al. 2001; Kim et al. 2006a, b; Gonzalez-Franco and Robles-Hernandez 2009), and other types of fungi (Adams and Fravel 1990; Jones et al. 2004; Alabouvette et al. 2009), also those interacting with hyper-parasitism (Whipps et al. 2008) are used in the biocontrol of phytopathogenic fungi. The viruses (mycoviruses) are the least known (Pearson et al. 2009), which in view are a very precise weapon that can limit phytopathogen populations and thus protect plant crops from epizootic mycosis. Viruses have great potential for their use 
against phytopathogenic fungi. Typically, these infections occur in chronic and latent form, but there are species of viruses capable of affecting the host phenotype, leading to hypovirulence, which is reduction of pathogenicity of the fungus against the plant organism (Nuss 2005; Pearson et al. 2009; Yu et al. 2010; Son et al. 2015). An example of hypovirulence is chestnut disease in Europe caused by Cryphonectria parasitica and controlled by hypovirulent fungal strains (Heiniger and Rigling 1994).

\section{Mykowirusy grzybów fitopatogennych / Mycoviruses of phytopathogenic fungi}

Biological activities of viruses associated with fungi were often speculated about in early observations. The first mention comes from 1936, when Wiebols and Wieringa observe an anomalous lysis in a yeast culture probably due to the presence of lysogenic virus (Wiebols and Wieringa 1936). Suspicions of the action of the virus infecting higher fungi come from 1950. Back then Sinden and Hauser described the degenerative changes of mushrooms recorded in the cultivated mushroom in a mushroom house owned by the La France brothers from Pennsylvania - hence one of the later name of the disease is "La France Disease" (Sinden and Hauser 1950). The infected mushrooms were characterized by distorted sporocarps, and also grew slowly and matured prematurely, resulting in significant crop losses (Son et al. 2015). Shortly thereafter, information about similar symptoms came from Europe, Australia and Japan. Suspicions were confirmed in 1962, when Hollings shared information about the research on the relationship between the disease of dieback mushroom (Agaricus bisporus) and the presence of viral particles genetic material. Three viral isolates discovered from hymenium were able to infect and cause disease in asymptomatic fungi (Hollings 1962). This discovery laid the foundations for the development of modern mycovirusology.

Viruses capable of using fungal cells for their own development are called mycoviruses (Ghabrial et al. 2015). The majority ofmycoviral genomes consist of double stranded RNA (dsRNA), while approximately $30 \%$ of positively charged single stranded RNA (+ ssRNA) is observed. Studies have shown that mycoviruses infect fungi from all major clusters, such as Chytridiomycota, Zygomycota, Ascomycota, Deuteromycota and Basidiomycota (Son et al. 2015).

Up to date, more than 80 species of mycoviruses capable of infecting phytopathogenic fungi have been discovered (Table 1). They were assigned to six families of linear dsRNAs (Chrysoviridae, Hypoviridae, Megabarniviridae, Partiviridae, Reoviridae, Totiviridae), four linear positive ssRNAs families (Alphaflexiviridae, Endornaviridae, Gammaflexiviridae and Narnaviridae), including one family of positive reverse transcriptase ssRNAs (Metaviridae), as well as many species not yet classified to any family with linear and circular genomes built with both RNA and DNA. Based on bibliographic data, a table has been compiled showing the majority of phytopathogenic fungi mycoviruses discovered up to date. It is very promising that there are identified mycoviruses capable of infecting half of the phytopathogenic fungi listed on the register of the 10 most important phytopathogens, including the phytopathogens from the top of the list (Magnaporthe oryzae virus 1 and 2, Botrytis virus X, Fusarium graminearum mycovirus-9, Fusarium graminearum dsRNA mycovirus 1, 2, 3 and 4, Fusarium oxysporum Skippy virus, Fusarium oxysporum chrysovirus 1, Ustilago maydis virus $\mathrm{H1}$ ), as well as significant but not listed $R$. solani (Rhizoctonia solani virus 717) (Strauss et al. 2000; Howit et al. 2006; Voth et al. 2006; Yokoi et al. 2007; Maejima et al. 2008; Yu et al. 2009; Sande et al. 2010; Darissa et al. 2011; Cho et al. 2013).

Over the years, through evolution, viruses have developed two ways of transmitting between organisms; intracellular and extracellular transmission, but up to date there is only one example in nature of extracellular transmission (Sande et al. 2010; Yu et al. 2013).

\section{Transmisja / Transmission}

Mycoviruses are mainly spread by vertical transmission, which occurs during the formation of asexual and sexually contaminated spores, where asexual spore is the most effective means of transmission (Sande et al. 2010). Transfers can also take place in a horizontal manner, when the hyphae of two fungi fuse resulting in heterokaryon formation (Hollings and Stone 1969; Lhoas 1971; Wood and Bozarth 1973; Van Diepeningen et al. 1998). Ability of the mycelium to connect to and exchange of protoplasm is therefore an important element contributing to the spread of infection associated with genetic molecules in populations of fungi occurring in nature (Caten 1972). The ability to carry out mycoviruses between genetically incompatible hyphae is also possible by using a protoplast fusion method in laboratory (Van Diepeningen et al. 1998). Using this method it is also possible to transfer viruses among fungi of different species (Van Diepeningen et al. 1998). The migration of mycoviruses using protoplast fusions has been observed in phytopathogenic fungi such as Fusarium poae (Van Diepeningen et al. 2000) and Rosellinia necatrix (Kanematsu et al. 2010).

Most studies have reported that mycoviruses are not infectious in the classical sense, because the infection can not be initiated by exposure of uninfected fungus to the purified virus particles (Ghabrial 1998). Extracellular infection can be achieved under special experimental conditions primarily through the use of protoplast fusion. Using this method, 
Tabela 1. Mykowirusy grzybów fitopatogennych

Table 1. Mycoviruses of phytopathogenic fungi

\begin{tabular}{|c|c|c|c|c|c|}
\hline $\begin{array}{l}\text { Genom } \\
\text { Genome }\end{array}$ & $\begin{array}{l}\text { Rodzina } \\
\text { Family }\end{array}$ & $\begin{array}{l}\text { Rodzaj } \\
\text { Genus }\end{array}$ & $\begin{array}{l}\text { Gatunek } \\
\text { Species }\end{array}$ & $\begin{array}{l}\text { Genbank } \\
\text { Genbank }\end{array}$ & $\begin{array}{l}\text { Źródło } \\
\text { Source }\end{array}$ \\
\hline 1 & 2 & 3 & 4 & 5 & 6 \\
\hline \multirow[t]{13}{*}{ ss(+)RNA } & \multirow[t]{2}{*}{ Alphaflexiviridae } & Sclerodarnavirus & $\begin{array}{l}\text { Sclerotinia sclerotiorum debilitation asso- } \\
\text { ciated RNA virus }\end{array}$ & NC_007415 & Xie et al. 2006 \\
\hline & & Botrexvirus & Botrytis virus $\mathrm{X}$ & NC_005132 & Howitt et al. 2006 \\
\hline & \multirow[t]{2}{*}{ Endornaviridae } & \multirow[t]{2}{*}{ Endornavirus } & Phytophthora endornavirus 1 & NC_007069 & Hacker et al. 2005 \\
\hline & & & Helicobasidium mompa endornavirus 1 & NC_013447 & Osaki et al. 2006 \\
\hline & Gammaflexiviridae & Mycoflexivirus & Botrytis virus $\mathrm{F}$ & NC_002604 & Howitt et al. 2001 \\
\hline & \multirow[t]{5}{*}{ Narnaviridae } & \multirow[t]{5}{*}{ Mitovirus } & Cryphonectria parasitica mitovirus 1 & NC_004046 & $\begin{array}{l}\text { Polashock and Hillman } \\
1994\end{array}$ \\
\hline & & & Ophiostoma mitovirus $3 \mathrm{a}$ & NC_004049 & Hong et al. 1998 \\
\hline & & & Ophiostoma mitovirus 4 & NC_004052 & Hong et al. 1999 \\
\hline & & & Ophiostoma mitovirus 5 & NC_004053 & Hong et al. 1999 \\
\hline & & & Ophiostoma mitovirus 6 & NC_004054 & Hong et al. 1999 \\
\hline & \multirow[t]{3}{*}{ Unclasified } & & Diaporthe ambigua RNA virus & NC_001278 & Preisig et al. 2000 \\
\hline & & & Sclerophthora macrospora virus A & NC_005817-..19 & Yokoi et al. 2003 \\
\hline & & & Sclerophthola macrospora virus B & NC_004714 & Yokoi et al. 1999 \\
\hline \multirow[t]{2}{*}{ ss(+)RNA-RT } & \multirow[t]{2}{*}{ Metaviridae } & \multirow[t]{2}{*}{ Metavirus } & Cladosporium fulvum $\mathrm{T}-1$ virus & Z11866 & Sande et al. 2010 \\
\hline & & & Fusarium oxysporum Skippy virus & L34658 & Sande et al. 2010 \\
\hline \multirow[t]{25}{*}{ dsRNA } & \multirow[t]{3}{*}{ Reoviridae } & \multirow[t]{3}{*}{ Mycoreovirus } & Cryphonectria parasitica mycoreovirus 1 & LC019123-..26 & Eusebio-Cope et al. 2010 \\
\hline & & & Cryphonectria parasitica mycoreovirus 2 & DQ902580 & Supyani et al. 2007 \\
\hline & & & Rosellinia necatrix mycoreovirus 3 & NC_007524-..36 & Osaki et al. 2002 \\
\hline & \multirow[t]{5}{*}{ Chrysoviridae } & \multirow[t]{4}{*}{ Chrysovirus } & Aspergillus fumigatus chrysovirus & FN178512-..15 & Jamal et al. 2010 \\
\hline & & & Fusarium graminearum dsRNA mycovirus 2 & HQ343295-..300 & Yu et al. 2009 \\
\hline & & & Fusarium oxysporum chrysovirus 1 & EF152346-...48 & Cho et al. 2013 \\
\hline & & & Helminthosporium victoriae $145 \mathrm{~S}$ virus & NC_005978-..81 & Ghabrial et al. 2002 \\
\hline & & Unclasified & Fusarium graminearum mycovirus-China 9 & HQ228213-..17 & Darissa et al. 2011 \\
\hline & \multirow[t]{17}{*}{ Partitiviridae } & \multirow[t]{7}{*}{ Partivirus } & Aspergillus fumigatus partitivirus 1 & $\begin{array}{l}\text { FN376847; } \\
\text { FN398100 }\end{array}$ & Bhatti et al. 2011 \\
\hline & & & Atkinsonella hypoxylon virus & NC_003470-..72 & Oh and Hillman 1995 \\
\hline & & & Fusarium solani virus 1 & D55668; D556689 & Nogawa et al. 1996 \\
\hline & & & Heterobasidion annosum virus & AF473549 & Ihrmark 2001 \\
\hline & & & Ophiostoma partitivirus 1 & AM087202-..03 & Crawford et al. 2006 \\
\hline & & & Ustilaginoidea virens partitivirus 1 & KC469949-..50 & Zhang et al. 2013 \\
\hline & & & Verticilium dahliae partivirus 1 & KC422243-...43 & Feng et al. 2013 \\
\hline & & Alphapartivirus & Helicobasidium mompa virus & AB110979 & Osaki et al. 2004 \\
\hline & & \multirow[t]{4}{*}{ Betapartivirus } & Ceratocystis resinifera virus 1 & NC_010754-...55 & Deng and Boland 2007 \\
\hline & & & Fusarium poae virus 1 & $\begin{array}{l}\text { NC_030877; } \\
\text { NC_003882-..84 }\end{array}$ & $\begin{array}{l}\text { Compel and Fekete } 1999 \\
\text { Osaki et al. } 2016\end{array}$ \\
\hline & & & Rhizoctonia solani virus 717 & NC_003801-..02 & Strauss et al. 2000 \\
\hline & & & Rosellinia necatrix virus 1 & NC_007537-...38 & Sasaki et al. 2006 \\
\hline & & \multirow[t]{5}{*}{ Gammapartivirus } & Aspergillus ochraceus virus FA0611 & EU118277-..79 & Liu et al. 2008 \\
\hline & & & Aspergillus ochraceus virus dsRNA1 & DQ270031 & Kim et al. 2006a \\
\hline & & & Discula destructiva virus 1 & $\begin{array}{l}\text { NC_002797; } \\
\text { NC_002800-..02 }\end{array}$ & Rong et al. 2002 \\
\hline & & & Discula destructiva virus 2 & NC_003710-..11 & Rong et al. 2002 \\
\hline & & & Gremmeniella abietina virus MS1 & NC_004018-..20 & $\begin{array}{l}\text { Tuomivirta and Hantula } \\
2003\end{array}$ \\
\hline
\end{tabular}


Tabela 1. Mykowirusy grzybów fitopatogennych - cd.

Table 1. Mycoviruses of phytopathogenic fungi - continued

\begin{tabular}{|c|c|c|c|c|c|}
\hline $\begin{array}{l}\text { Genom } \\
\text { Genome }\end{array}$ & $\begin{array}{l}\text { Rodzina } \\
\text { Family }\end{array}$ & $\begin{array}{l}\text { Rodzaj } \\
\text { Genus }\end{array}$ & $\begin{array}{l}\text { Gatunek } \\
\text { Species }\end{array}$ & $\begin{array}{l}\text { Genbank } \\
\text { Genbank }\end{array}$ & $\begin{array}{l}\text { Źródło } \\
\text { Source }\end{array}$ \\
\hline \multirow[t]{43}{*}{1} & 2 & 3 & 4 & 5 & 6 \\
\hline & & \multirow[t]{6}{*}{ Unclasified } & Fusarium graminearum dsRNA mycovirus 4 & NC_013470-..71 & Yu et al. 2009 \\
\hline & & & Botryosphaeria dothidea virus 1 & KT372135-..39 & Wang et al. 2014 \\
\hline & & & Verticillium albo-atrum partitivirus-1 & KJ476945-..46 & Cañizares et al. 2014 \\
\hline & & & Rosellinia necatrix partitivirus 3 & AB698491 & Yaegashi et al. 2013 \\
\hline & & & Rosellinia necatrix partitivirus 4 & AB698493 & Yaegashi et al. 2013 \\
\hline & & & Rosellinia necatrix partitivirus 5 & AB698494 & Yaegashi et al. 2013 \\
\hline & \multirow[t]{18}{*}{ Totiviridae } & \multirow[t]{7}{*}{ Totivirus } & Aspergillus mycovirus 178 & EU289894-..95 & Hammond et al. 2008 \\
\hline & & & Aspergillus mycovirus 1816 & EU289896 & Hammond et al. 2008 \\
\hline & & & Botryotina fuckeliana totivirus 1 & NC_009224 & De Guido et al. 2005 \\
\hline & & & $\begin{array}{l}\text { Helicobasidium mompa V670 L2-dsRNA } \\
\text { virus }\end{array}$ & AB27528-..89 & Suzaki 2006b \\
\hline & & & Helicobasidium mompa dsRNA virus N10 & AB253329 & Suzaki 2006a \\
\hline & & & Helicobasidium mompa dsRNA virus V169 & AB253401 & Suzaki 2006a \\
\hline & & & Ustilago maydis virus $\mathrm{H} 1$ & NC_003823 & Voth et al. 2006 \\
\hline & & \multirow[t]{10}{*}{ Victorivirus } & Aspergillus foetidus slow virus 1 & HE588147 & Sande et al. 2010 \\
\hline & & & Chalara elegans RNA virus 1 & NC_005883 & Park et al. 2005 \\
\hline & & & Gremmeniella abietina RNA virus L1 & NC_003876 & $\begin{array}{l}\text { Tuomivirta and Hantula } \\
2003\end{array}$ \\
\hline & & & Helicobasidium mompa totivirus 1-17 & NC_005074-..75 & Nomura et al. 2003 \\
\hline & & & Helminthosporium victoriae virus $190 \mathrm{~S}$ & NC_003607 & $\begin{array}{l}\text { Huang and Ghabrial } \\
1996\end{array}$ \\
\hline & & & Magnaporthe oryzae virus 1 & NC_006367 & Yokoi et al. 2007 \\
\hline & & & Magnaporthe oryzae virus 2 & NC_010246 & Maejima et al. 2008 \\
\hline & & & Rosellinia necatrix victorivirus 1 & NC_021565 & Chiba et al. 2013 \\
\hline & & & Sphaeropsis sapinea RNA virus 1 & NC_001963 & Preisig et al. 1998 \\
\hline & & & Sphaeropsis sapinea RNA virus 2 & NC_001964 & Preisig et al. 1998 \\
\hline & & Unclasified & Fusarium graminearum dsRNA mycovirus 3 & NC_013469 & Yu et al. 2009 \\
\hline & \multirow[t]{6}{*}{ Hypoviridae } & \multirow[t]{6}{*}{ Hypovirus } & Cryphonectria hypovirus 1 & \begin{tabular}{|l|} 
JQ778851-..52 \\
NC_001492
\end{tabular} & $\begin{array}{l}\text { Brusini and Robin } 2013 \\
\text { Shapira et al. } 1991\end{array}$ \\
\hline & & & Cryphonectria hypovirus 1-EP713 & - & Sun et al. 2006 \\
\hline & & & Cryphonectria hypovirus 1-Euro7 & - & Sasaki 2009 \\
\hline & & & Cryphonectria hypovirus 2-NB58 & CRPMRNA & Hillman et al. 1994 \\
\hline & & & Cryphonectria hypovirus 3 & NC_000960 & Smart et al. 1999 \\
\hline & & & Cryphonectria hypovirus 4 & NC_006431 & Linder-Basso et al. 2005 \\
\hline & Megabirnaviridae & Megabirnavirus & Rosellinia necatrix megabirnavirus 1/W779 & AB512282-..83 & Chiba et al. 2009 \\
\hline & \multirow[t]{11}{*}{ Unclasified } & & Alternaria alternata virus 1 & AB368492; & Aoki et al. 2009 \\
\hline & & & Aspergillus foetidus dsRNA mycovirus & NC_020100-..03 & Kozlakidis et al. 2013 \\
\hline & & & Aspergillus foetidus slow virus 2 & HE588148 & Kozlakidis et al. 2013 \\
\hline & & & Aspergillus foetidus virus satellite RNA & LN614706 & Shah et al. 2015 \\
\hline & & & Aspergillus fumigatus tetramycovirus 1 & HG975302-..05 & Kanhayuwa et al. 2015 \\
\hline & & & Aspergillus mycovirus 341 & EU289897 & Hammond et al. 2008 \\
\hline & & & $\begin{array}{l}\text { Fusarium graminearum dsRNA mycovirus } \\
1 \text { strain DK- } 21\end{array}$ & AY533037 & Kwon et al. 2007 \\
\hline & & & Rosellinia necatrix mycovirus 1-W1032/S5 & LC061478 & Zhang et al. 2016 \\
\hline & & & Rosellinia necatrix mycovirus 2-W1032/S6 & LC006253 & Zhang et al. 2016 \\
\hline & & & Rosellinia necatrix mycovirus 3 -NW10/N10 & AB698498 & Yaegashi et al. 2013 \\
\hline & & & Sclerotinia sclerotiorum RNA virus L & EU779934 & Liu et al. 2009 \\
\hline ssDNA & Unclasified & & $\begin{array}{l}\text { Sclerotinia sclerotiorum hypovirulence } \\
\text { associated DNA virus } 1\end{array}$ & \begin{tabular}{|l|} 
KF268025-..28 \\
KM598382-..84 \\
\end{tabular} & $\begin{array}{l}\text { Kraberger et al. } 2013 \\
\text { Dayaram et al. } 2015 \\
\end{array}$ \\
\hline dsDNA & Unclasified & & $\begin{array}{l}\text { Cryphonectria parasitica bipartite myco- } \\
\text { virus } 1\end{array}$ & NC_021222-..23 & Deng et al. 2007 \\
\hline
\end{tabular}


purified viral particles belonging to the families of dsRNAs Partiviridae, Totiviriade, Reoviridae and Geminiviridae are able to successfully infect fungal protoplasts of $R$. necatrix (Sasaki et al. 2006), C. parasitica (Hillman and Suzuki 2004) and Sclerotinia sclerotiorum (Yu et al. 2010, 2013).

Up to date there is only one exception, which shows extracellular transmission in nature. $\mathrm{Yu}$ and colleagues demonstrated, that the viral particles SsHADV-1 (Sclerotinia sclerotiorum hypovirulence-associated DNA virus 1) can infect hyphae of S. sclerotiorum by extracellular way (Yu et al. 2013). Compared to experiments with fusion of protoplasts, in this case the infection was possible on intact cells of $S$. sclerotiorum. Based on the results of SsHADV-1 studies, it has been suggested that viral particles are required to infect undamaged cells or fungal protoplasts because naked viral DNA is not infectious (Yu et al. 2013). At the same time SsHADV-1-like viruses were recorded in different species of dragonflies, which act like vectors accumulating viruses from their insect prey (Liu et al. 2011).

\section{Objawy związane z zakażeniem mykowirusowym I Symptoms related to mycoviral infection}

Usually mycoviruses cause latent and chronic infections (Pearson et al. 2009; Son et al. 2015), but some of them are associated with a variable effect on the phenotype. Mycoviruses were able to coexist in association with their hosts, which could have resulted in the reduction of fungal infections (Van Diepeningen et al. 2008). Nonetheless, mycoviral infections that are harmful to fungi have been observed (Nuss 2005; Yu et al. 2010).

Mycoviruses interfering with the fungal genotype change their phenotypic image, as shown in the following examples: Alternaria alternata - reduced mycelial growth rate, subsidence of airway mycelium, irregular pigmentation, cytolisis (Fuke et al. 2011), F. graminearum, occurrence of double stranded viral RNA was associated with a reduction in pathogenicity (trials on wheat) and deoxynivalenol production, as compared to wheat infected by samples free of viral RNA (Chu et al. 2002), abnormal colony morphology, perythecium developmental defects, growth retardation and sporulation (Lee et al. 2014), in turn in C. parasitica reduction of orange pigment production, changes in colony morphology, decreased production of oxalic acid, decreased ability to produce conidia, reduction of sporulation, morphological changes of plant carcinomas and increased or decreased growth rate (depending on viral strain) (Deng et al. 2007). The effects of infection such as sporulation reduction or reduced growth rate, are directly related to the phenomenon of hypovirulence, thus the pathogenicity of the fungus is reduced to the plant. This phenomenon is also caused by viruses of other phytopathogenic fungi, like Diaporthe perjuncta, Sclerotinia homoeocarpa, Ophiostoma ulmi, Ophiostoma novo-ulmi, R. solani, Helminthosporium victoriae and $R$. necatrix (Lakshman et al. 1998; Hong et al. 1999; Preisig et al. 2000; Ghabrial et al. 2002; Wei et al. 2003; Kanematsu et al. 2004; Deng et al. 2005; Nuss 2005; Wang et al. 2014).

\section{Wnioski / Conclusions}

Phytopathogenic fungi are an important and current problem in the cultivation of various plants worldwide, and in particular cereal crops. Commonly used chemicals in the form of fungicides pose a threat to the health of many living organisms, including humans, so it is important to find alternative ways to control pathogenic fungi. One of the promising directions is the use of biological plant protection agents. There is a great potential for mycoviruses, with emphasis on the fact that they were isolated from fungi that have the greatest negative impact on many crops. Mycoviral infections are often latent, but some of them affect the phenotype of the fungus. Among the most important changes should be the reduction of sporulation, reduced growth rate, limited mycelial growth or reduction of pigment production. A significant effect of mycoviral infection in the fungal cell is the development of hypovirulence, i.e. the reduction of the pathogenicity of the fungus what was experimentally confirmed in the phytopathogen of the species $F$. graminearum. Reduced dye production has been reported so far in the phytopathogenic fungus $C$. parasitica as well as $A$. alternata.

In conclusion, the discovery of mycoviruses has farreaching implications, so that over the decades we have learned many mechanisms that should be used as soon as possible in the control against phytopathogenic fungi. For this purpose, further interdisciplinary research in the fields of mycovirology, mycology, genetics, toxicology, and ecology is needed to comprehensively get to know the mycoviruses already identified. It is also expected to discover new species that may have in their genomes indescribable genes, potentially affecting the mechanisms of antifungal activity.

\section{Literatura / References}

Adams P.B., Fravel D.R. 1990. Economical biological control of Sclerotinia lettuce drop by Sporidesmium sclerotivorum. Phytopathology 80 (10): 1120-1124. DOI: 10.1094/Phyto-80-1120.

Alabouvette C., Olivain C., Migheli Q., Steinberg C. 2009. Microbiological control of soil-borne phytopathogenic fungi with special emphasis on wilt-inducing Fusarium oxysporum. New Phytologist 184 (3): 529-544. DOI: 10.1111/j.1469-8137.2009.03014.x. 
Aoki N., Moriyama H., Kodama M., Arie T., Teraoka T., Fukuhara T. 2009. A novel mycovirus associated with four double-stranded RNAs affects host fungal growth in Alternaria alternata. Virus Research 140 (1-2): 179-187. DOI: 10.1016/j.virusres.2008.12.003.

Bhatti M.F., Bignell E.M., Coutts R.H.H. 2011. Complete nucleotide sequences of two dsRNAs associated with a new partitivirus infecting Aspergillus fumigatus. Archives of Virology 156 (9): 1677-1680. DOI: 10.1007/s00705-011-1045-5.

Blackwell M. 2011. The Fungi: 1, 2, 3 .. 5.1 million species? American Journal of Botany 98 (3): 426-438. DOI: 10.3732/ajb.1000298.

Blair A., Dosemeci M., Heineman E.F. 1993. Cancer and other causes of death among male and female farmers from twenty-three states. American Journal of Industrial Medicine 23 (5): 729-742. DOI: 10.1002/ajim.4700230507.

Brusini J., Robin C. 2013. Mycovirus transmission revisited by in situ pairings of vegetatively incompatible isolates of Cryphonectria parasitica. Journal of Virological Methods 187 (2): 435-442. DOI: 10.1016/j.jviromet.2012.11.025.

Calhelha R.C., Andrade J.V., Ferreira I.C., Estevinho L.M. 2006. Toxicity effects of fungicide residues on the wine-producing process. Food Microbiology 23 (4): 393-398. DOI: 10.1016/j.fm.2005.04.008.

Campbell R. 1989. Biological control of microbial plant pathogens. Cambridge University Press, Cambridge, 67 ss. ISBN 0-52134900-1.

Cañizares M.C., Pérez-Artés E., García-Pedrajas M.D. 2014. The complete nucleotide sequence of a novel partitivirus isolated from the plant pathogenic fungus Verticillium albo-atrum. Archives of Virology 159 (11): 3141-3144. DOI: 10.1007/s00705-014-2156-6.

Carris L.M., Little C.R., Stiles C.M. 2012. Introduction to fungi. The plant health instructor. DOI: 10.1094/PHI-I-2012-0426-01.

Caten C.E. 1972. Vegetative incompatibility and cytoplasmic infection in fungi. Microbiology 72 (2): 221-229. DOI: 10.1099/00221287$72-2-221$.

Chiba S., Lin Y.H., Kondo H., Kanematsu S., Suzuki N. 2013. A novel victorivirus from a phytopathogenic fungus, Rosellinia necatrix, is infectious as particles and targeted by RNA silencing. Journal of Virology 87 (12): 6727-6738. DOI: 10.1128/JVI.00557-13.

Chiba S., Salaipeth L., Lin Y.H., Sasaki A., Kanematsu S., Suzuki N. 2009. A novel bipartite double-stranded RNA mycovirus from the white root rot fungus Rosellinia necatrix: molecular and biological characterization, taxonomic considerations, and potential for biological control. Journal of Virology 83 (24): 12801-12812. DOI: 10.1128/JVI.01830-09.

Cho W.K., Lee K.M., Yu J., Son M., Kim K.H. 2013. Insight into mycoviruses infecting Fusarium species. Advances in Virus Research 86: 273-288. DOI: 10.1016/B978-0-12-394315-6.00010-6.

Chu Y.M., Jeon J.J., Yea S.J., Kim Y.H., Yun S.H., Lee Y.W., Kim K.H. 2002. Double-stranded RNA mycovirus from Fusarium graminearum. Applied and Environmental Microbiology 68 (5): 2529-2534. DOI: 10.1128/AEM.68.5.2529-2534.2002.

Clark D.P. 2010. Germs, Genes, \& Civilization: How Epidemics Shaped Who We Are Today. Financial Times Press, New Jersey, 261 ss. ISBN 0-13-701996-3.

Compel P., Fekete C. 1999. Genetic interrelationships and genome organization of double-stranded RNA elements of Fusarium poae. Virus Genes 18 (1): 49-56. DOI: 10.1023/A:1008069318838.

Crawford L.J., Osman T.A., Booy F.P., Coutts R.H., Brasier C.M., Buck K.W. 2006. Molecular characterization of a partitivirus from Ophiostoma himal-ulmi. Virus Genes 33 (1): 33-39. DOI: 10.1007/s11262-005-0028-6.

Darissa O., Willingmann P., Schäfer W., Adam G. 2011. A novel double-stranded RNA mycovirus from Fusarium graminearum: nucleic acid sequence and genomic structure. Archives of Virology 156 (4): 647-658. DOI: 10.1007/s00705-010-0904-9.

Dayaram A., Potter K.A., Pailes R., Marinov M., Rosenstein D.D., Varsani A. 2015. Identification of diverse circular single-stranded DNA viruses in adult dragonflies and damselflies (Insecta: Odonata) of Arizona and Oklahoma, USA. Infection, Genetics and Evolution 30: 278-287. DOI: 10.1016/j.meegid.2014.12.037.

De Guido M.A., Minafra A., Santomauro A., Pollastro S., De Miccolis Angelini R.M., Faretra F. 2005. Molecular characterization of mycoviruses from Botryotinia fuckeliana. Journal of Plant Pathology 87 (4): 293.

Dean R., Van Kan J.A., Pretorius Z.A., Hammond-Kosack K.E., Di Pietro A., Spanu P.D., Rudd J.J., Dickman M., Kahmann R., Ellis J., Foster G.D. 2012. The Top 10 fungal pathogens in molecular plant pathology. Molecular Plant Pathology 13 (4): 414-430. DOI: 10.1111/j.1364-3703.2011.00783.x.

Deangelis Y.M., Gemmer C.M., Kaczvinsky J.R., Kenneally D.C., Schwartz J.R., Dawson T.L. 2005. Three etiologic facets of dandruff and seborrheic dermatitis: Malassezia fungi, sebaceous lipids, and individual sensitivity. Journal of Investigative Dermatology Symposium Proceedings 10 (3): 295-297. DOI: 10.1111/j.1087-0024.2005.10119.x.

Deng F., Allen T.D., Hillman B.I., Nuss D.L. 2007. Comparative analysis of alterations in host phenotype and transcript accumulation following hypovirus and mycoreovirus infections of the chestnut blight fungus Cryphonectria parasitica. Eukaryotic Cell 6 (8): 1286-1298. DOI: 10.1128/EC.00166-07.

Deng F., Boland G.J. 2007. Natural occurrence of a partitivirus in the sapstaining fungus Ceratocystis resinifera. Canadian Journal of Plant Pathology 29 (2): 182-189. DOI: 10.1080/07060660709507455.

Deng F., Xu R., Boland G.J. 2005. Hypovirulence-associated double-stranded RNA from Sclerotinia homoeocarpa is conspecific with Ophiostoma novo-ulmi mitovirus 3a-Ld. Phytopathology 93 (11): 1407-1414. DOI: 10.1094/PHYTO.2003.93.11.1407.

Ellis S.D., Boehm M.J., Mitchell T.K. 2008. Fungal and fungal-like diseases of plants. Fact Sheet, Agriculture and Natural Resources, The Ohio State University, PP401.07: 1-4.

Eusebio-Cope A., Sun L., Hillman B.I., Suzuki N. 2010. Mycoreovirus 1 S4-coded protein is dispensable for viral replication but necessary for efficient vertical transmission and normal symptom induction. Virology 397 (2): 399-408. DOI: 10.1016/j.virol.2009.11.035.

Feng Z., Zhu H., Li Z., Shi Y., Zhao L., Liu L., Jiang D. 2013. Complete genome sequence of a novel dsRNA mycovirus isolated from the phytopathogenic fungus Verticillium dahliae Kleb. Archives of Virology 158 (12): 2621-2623. DOI: 10.1007/s00705-013-1774-8.

Fuke K., Takeshita K., Aoki N., Fukuhara T., Egusa M., Kodama M., Moriyama H. 2011. The presence of double-stranded RNAs in Alternaria alternata Japanese pear pathotype is associated with morphological changes. Journal of General Plant Pathology 77 (4): 248-252. DOI: 10.1007/s10327-011-0315-0.

Garry V.F., Harkins M.E., Erickson L.L., Long-Simpson L.K., Holland S.E., Burroughs B.L. 2002. Birth defects, season of conception, and sex of children born to pesticide applicators living in the Red River Valley of Minnesota, USA. Environmental Health Perspectives 110 (3): 441-449. DOI: 10.1289/ehp.02110s3441.

Ghabrial S.A. 1998. Origin, adaptation and evolutionary pathways of fungal viruses. Virus Genes 16 (1): 119-131. DOI: 10.1023/ A:1007966229595.

Ghabrial S.A., Castón J.R., Jiang D., Nibert M.L., Suzuki N. 2015. 50-plus years of fungal viruses. Virology 479-480: 356-368. DOI: 10.1016/j.virol.2015.02.034. 
Ghabrial S.A., Soldevila A.I., Havens W.M. 2002. Molecular genetics of the viruses infecting the plant pathogenic fungus Helminthosporium victoriae. Chapter 9. s. 213-236. W: dsRNA Genetic Elements: Concepts and Applications in Agriculture, Forestry and Medicine (S.M. Tavantzis, red.). CRC Press LLC, Boca Raton, Florida, USA, 283 ss. ISBN 0-8493-2205-7.

Gonzalez-Franco C.A., Robles-Hernandez R.Y. 2009. Actinomycetes as biological control agents of phytopathogenic fungi. Tecnociencia Chihuahua 3 (2): 64-73.

Gray L.E., Ostby J.S., Kelce W.R. 1994. Developmental effects of an environmental antiandrogen: the fungicide vinclozolin alters sex differentiation of the male rat. Toxicology and Applied Pharmacology 129 (1): 46-52. DOI: 10.1006/taap.1994.1227.

Hacker C.V., Brasier C.M., Buck K.W. 2005. A double-stranded RNA from a Phytophthora species is related to the plant endornaviruses and contains a putative UDP glycosyltransferase gene. Journal of General Virology 86 (5): 1561-1570. DOI: 10.1099/vir.0.80808-0.

Hammond T.M., Andrewski M.D., Roossinck M.J., Keller N.P. 2008. Aspergillus mycoviruses are targets and suppressors of RNA silencing. Eukaryotic Cell 7 (2): 350-357. DOI: 10.1128/EC.00356-07.

Hawksworth D.L. 2001. The magnitude of fungal diversity: the 1.5 million species estimate revisited. Mycological Research 105 (12): 1422-1432. DOI: 10.1017/S0953756201004725.

Heiniger U., Rigling D. 1994. Biological control of chestnut blight in Europe. Annual Review of Phytopathology 32 (1): 581-599. DOI: 10.1146/annurev.py.32.090194.003053.

Hillman B.I., Halpern B.T., Brown M.P. 1994. A viral dsRNA element of the chestnut blight fungus with a distinct genetic organization. Virology 201 (2): 241-250. DOI: 10.1006/viro.1994.1289.

Hillman B.I., Suzuki N. 2004. Viruses of the chestnut blight fungus, Cryphonectria parasitica. s. 423-472. W: Advances in Virus Research Volume 63 (K. Maramorosch, A.J. Shatkin, red.). Elsevier Academic Press, San Diego, California, USA, 473 ss. ISBN 0-12039865-6.

Hollings M. 1962. Viruses associated with a die-back disease of cultivated mushroom. Nature 196 (4858): 962-965. DOI: $10.1038 / 196962 \mathrm{a} 0$

Hollings M., Stone O.M. 1969. Viruses in fungi. Science Progress (1933-) 57 (227): 371-391.

Hong Y., Cole T.E., Brasier C.M., Buck K.W. 1998. Evolutionary relationships among putative RNA-dependent RNA polymerases encoded by a mitochondrial virus-like RNA in the dutch elm disease fungus, Ophiostoma novo-ulmi, by other viruses and virus-like RNAs and by the Arabidopsis mitochondrial genome. Virology 246 (1): 158-169. DOI: 10.1006/viro.1998.9178.

Hong Y., Dover S.L., Cole T.E., Brasier C.M., Buck K.W. 1999. Multiple mitochondrial viruses in an isolate of the Dutch elm disease fungus Ophiostoma novo-ulmi. Virology 258 (1): 118-127. DOI: 10.1006/viro.1999.9691.

Howitt R.L., Beever R.E., Pearson M.N., Forster R.L. 2001. Genome characterization of Botrytis virus F, a flexuous rod-shaped mycovirus resembling plant 'potex-like' viruses. Journal of General Virology 82 (1): 67-78. DOI: 10.1099/0022-1317-82-1-67.

Howitt R.L.J., Beever R.E., Pearson M.N., Forster R.L.S. 2006. Genome characterization of a flexuous rod-shaped mycovirus, Botrytis virus X, reveals high amino acid identity to genes from plant 'potex-like' viruses. Archives of Virology 151 (3): 563-579. DOI: $10.1007 / \mathrm{s} 00705-005-0621-\mathrm{y}$.

Huang S., Ghabrial S.A. 1996. Organization and expression of the double-stranded RNA genome of Helminthosporium victoriae $190 \mathrm{~S}$ virus, a totivirus infecting a plant pathogenic filamentous fungus. Proceedings of the National Academy of Sciences 93 (22): 12541-12546. DOI: 10.1073/pnas.93.22.12541.

Ihrmark K. 2001. Double-stranded RNA elements in the root rot fungus Heterobasidion annosum (Doctoral thesis). Swedish University of Agricultural Sciences, Uppsalla. http://pub.epsilon.slu.se/4/1/91-576-6094-8.fulltext.pdf [dostęp: 30.08.2019].

Jamal A., Bignell E.M., Coutts R.H. 2010. Complete nucleotide sequences of four dsRNAs associated with a new chrysovirus infecting Aspergillus fumigatus. Virus Research 153 (1): 64-70. DOI: 10.1016/j.virusres.2010.07.008.

Jones E.E., Mead A., Whipps J.M. 2004. Effect of inoculum type and timing of application of Coniothyrium minitans on Sclerotinia sclerotiorum: control of sclerotinia disease in glasshouse lettuce. Plant Pathology 53 (5): 611-620. DOI: 10.1111/j.13653059.2004.01071.x.

Kamel F., Hoppin J.A. 2004. Association of pesticide exposure with neurologic dysfunction and disease. Environmental Health Perspectives 112 (9): 950-958. DOI: 10.1289/ehp.7135.

Kamrin M.A. (red.) 1997. Pesticide Profiles: Toxicity, Environmental Impact, and Fate. 1st Edition. CRC Press, New York, 704 ss. ISBN 9781566701907.

Kanematsu S., Arakawa M., Oikawa Y., Onoue M., Osaki H., Nakamura H., Ikeda K., Kuga-Uetake Y., Nitta H., Sasaki A., Suzaki K., Yoshida K., Matsumoto N. 2004. A reovirus causes hypovirulence of Rosellinia necatrix. Phytopathology 94 (6): 561-568. DOI: 10.1094/PHYTO.2004.94.6.561.

Kanematsu S., Sasaki A., Onoue M., Oikawa Y., Ito T. 2010. Extending the fungal host range of a partitivirus and a mycoreovirus from Rosellinia necatrix by inoculation of protoplasts with virus particles. Virology 100 (9): 922-930. DOI: 10.1094/PHYTO-1009-0922.

Kanhayuwa L., Kotta-Loizou I., Özkan S., Gunning A.P., Coutts R.H. 2015. A novel mycovirus from Aspergillus fumigatus contains four unique dsRNAs as its genome and is infectious as dsRNA. Proceedings of the National Academy of Sciences 112 (29): 9100-9105. DOI: $10.1073 /$ pnas.1419225112.

Kim J.W., Choi E.Y., Kim Y.T. 2006a. Intergeneric relationship between the Aspergillus ochraceous virus F and the Penicillium stoloniferum virus S. Virus Research 120 (1-2): 212-215. DOI: 10.1016/j.virusres.2006.04.004.

Kim H.J., Lee S.C., Hwang B.K. 2006b. Streptomyces cheonanensis sp. nov., a novel streptomycete with antifungal activity. International Journal of Systematic and Evolutionary Microbiology 56 (2): 471-475. DOI: 10.1099/ijs.0.63816-0.

Kirk P.M., Cannon P.F., Minter D.W., Stalpers J.A. (red.) 2008. Dictionary of the Fungi. 10th Edition. CAB International, Wallingford, UK, 784 ss. ISBN 0851998267.

Knogge W. 1996. Molecular basis of specificity in host/fungus interactions. European Journal of Plant Pathology 102 (9): 807-816. DOI: $10.1007 / \mathrm{BF} 01877049$.

Kozlakidis Z., Herrero N., Ozkan S., Kanhayuwa L., Jamal A., Bhatti M.F., Coutts R.H. 2013. Sequence determination of a quadripartite dsRNA virus isolated from Aspergillus foetidus. Archives of Virology 158 (1): 267-272. DOI: 10.1007/s00705-012-1362-3.

Kraberger S., Stainton D., Dayaram A., Zawar-Reza P., Gomez C., Harding J.S., Varsani A. 2013. Discovery of Sclerotinia sclerotiorum hypovirulence-associated virus-1 in urban river sediments of Heathcote and Styx rivers in Christchurch city, New Zealand. Genome Announcements 1 (4): e00559-13. DOI: 10.1128/genomeA.00559-13. 
Kulik M.M. 1995. The potential for using cyanobacteria (blue-green algae) and algae in the biological control of plant pathogenic bacteria and fungi. European Journal of Plant Pathology 101 (6): 585-599. DOI: 10.1007/BF01874863.

Kwon S.J., Lim W.S., Park S.H., Park M.R., Kim K.H. 2007. Molecular characterization of a dsRNA mycovirus, Fusarium graminearum virus-DK21, which is phylogenetically related to hypoviruses but has a genome organization and gene expression strategy resembling those of plant potex-like viruses. Molecules and Cells 23 (3): 304-315.

Lakshman D.K., Jian J., Tavantzis S.M. 1998. A double-stranded RNA element from a hypovirulent strain of Rhizoctonia solani occurs in DNA form and is genetically related to the pentafunctional AROM protein of the shikimate pathway. Proceedings of the National Academy of Sciences 95 (11): 6425-6429. DOI: 10.1073/pnas.95.11.6425.

Lee K.M., Cho W.K., Yu J., Son M., Choi H., Min K., Yin-Won L., Kim K.H. 2014. A comparison of transcriptional patterns and mycological phenotypes following infection of Fusarium graminearum by four mycoviruses. PloS One 9 (6): e100989. DOI: 10.1371/ journal.pone.0100989.

Lhoas P. 1971. Transmission of double stranded RNA viruses to a strain of Penicillium stoloniferum through heterokaryosis. Nature 230: 248-249. DOI: 10.1038/230248a0.

Linder-Basso D., Dynek J.N., Hillman B.I. 2005. Genome analysis of Cryphonectria hypovirus 4, the most common hypovirus species in North America. Virology 337 (1): 192-203. DOI: 10.1016/j.virol.2005.03.038.

Liu W., Duns G., Chen J. 2008. Genomic characterization of a novel partitivirus infecting Aspergillus ochraceus. Virus Genes 37 (3): 322-327. DOI: 10.1007/s11262-008-0265-6.

Liu H., Fu Y., Jiang D., Li G., Xie J., Peng Y., Ghabrial S.A. 2009. A novel mycovirus that is related to the human pathogen hepatitis E virus and rubi-like viruses. Journal of Virology 83 (4): 1981-1991. DOI: 10.1128/JVI.01897-08.

Liu H., Fu Y., Li B., Yu X., Xie J., Cheng J., Ghabrial S.A., Li G., Yi X., Jiang D. 2011. Widespread horizontal gene transfer from circular single-stranded DNA viruses to eukaryotic genomes. BMC Evolutionary Biology 11 (1): 276. DOI: 10.1186/1471-2148-11-276.

Maejima K., Himeno M., Komatsu K., Kakizawa S., Yamaji Y., Hamamoto H., Namba S. 2008. Complete nucleotide sequence of a new double-stranded RNA virus from the rice blast fungus, Magnaporthe oryzae. Archives of Virology 153 (2): 389-391. DOI: 10.1007/ s00705-007-1101-3.

Meyling N.V., Eilenberg J. 2007. Ecology of the entomopathogenic fungi Beauveria bassiana and Metarhizium anisopliae in temperate agroecosystems: potential for conservation biological control. Biological Control 43 (2): 145-155. DOI: 10.1016/j. biocontrol.2007.07.007.

Nogawa M., Kageyama T., Nakatani A., Taguchi G., Shimosaka M., Okazaki M. 1996. Cloning and characterization of mycovirus doublestranded RNA from the plant pathogenic fungus, Fusarium solani f. sp. robiniae. Bioscience, Biotechnology, and Biochemistry 60 (5): 784-788. DOI: $10.1271 / \mathrm{bbb} .60 .784$.

Nomura K., Osaki H., Iwanami T., Matsumoto N., Ohtsu Y. 2003. Cloning and characterization of a totivirus double-stranded RNA from the plant pathogenic fungus, Helicobasidium mompa Tanaka. Virus Genes 26 (3): 219-226. DOI: 10.1023/A:1024453111809.

Nuss D.L. 2005. Hypovirulence: mycoviruses at the fungal-plant interface. Nature Reviews Microbiology 3 (8): 632-642. DOI: 10.1038/ nrmicro1206.

Oh C.S., Hillman B.I. 1995. Genome organization of a partitivirus from the filamentous ascomycete Atkinsonella hypoxylon. Journal of General Virology 76 (6): 1461-1470. DOI: 10.1099/0022-1317-76-6-1461.

Osaki H., Nakamura H., Sasaki A., Matsumoto N., Yoshida K. 2006. An endornavirus from a hypovirulent strain of the violet root rot fungus, Helicobasidium mompa. Virus Research 118 (1-2): 143-149. DOI: 10.1016/j.virusres.2005.12.004.

Osaki H., Nomura K., Matsumoto N., Ohtsu Y. 2004. Characterization of double-stranded RNA elements in the violet root rot fungus Helicobasidium mompa. Mycological Research 108 (6): 635-640. DOI: DOI: 10.1017/S095375620400005X.

Osaki H., Sasaki A., Nomiyama K., Tomioka K. 2016. Multiple virus infection in a single strain of Fusarium poae shown by deep sequencing. Virus Genes 52 (6): 835-847. DOI: 10.1007/s11262-016-1379-x.

Osaki H., Wei C.Z., Arakawa M., Iwanami T., Nomura K., Matsumoto N., Ohtsu Y. 2002. Nucleotide sequences of double-stranded RNA segments from a hypovirulent strain of the white root rot fungus Rosellinia necatrix: possibility of the first member of the Reoviridae from fungus. Virus Genes 25 (1): 101-107. DOI: 10.1023/A:1020182427439.

Parfrey L.W., Lahr D.J., Knoll A.H., Katz L.A. 2011. Estimating the timing of early eukaryotic diversification with multigene molecular clocks. Proceedings of the National Academy of Sciences 108 (33): 13624-13629. DOI: 10.1073/pnas.1110633108.

Park Y., James D., Punja Z.K. 2005. Co-infection by two distinct totivirus-like double-stranded RNA elements in Chalara elegans (Thielaviopsis basicola). Virus Research 109 (1): 71-85. DOI: 10.1016/j.virusres.2004.10.011.

Paro R., Tiboni G.M., Buccione R., Rossi G., Cellini V., Canipari R., Cecconi S. 2012. The fungicide mancozeb induces toxic effects on mammalian granulosa cells. Toxicology and Applied Pharmacology 260 (2): 155-161. DOI: 10.1016/j.taap.2012.02.005.

Patpour M., Hovmøller M., Justesen A., Newcomb M., Olivera P., Jin Y., Szabo L.J., Hodson D., Shanin A.A., Wanyera R., Habarurema I., Wobibi S. 2016. Emergence of virulence to SrTmp in the Ug99 race group of wheat stem rust, Puccinia graminis f. sp. tritici, in Africa. Plant Disease 100 (2): 522. DOI: 10.1094/PDIS-06-15-0668-PDN.

Pearson M.N., Beever R.E., Boine B., Arthur K. 2009. Mycoviruses of filamentous fungi and their relevance to plant pathology. Molecular Plant Pathology 10 (1): 115-128. DOI: 10.1111/j.1364-3703.2008.00503.x.

Peraica M., Radic B., Lucic A., Pavlovic M. 1999. Toxic effects of mycotoxins in humans. Bulletin of the World Health Organization 77 (9): 754-766.

Petit A.N., Fontaine F., Clément C., Vaillant-Gaveau N. 2008. Photosynthesis limitations of grapevine after treatment with the fungicide fludioxonil. Journal of Agricultural and Food Chemistry 56 (15): 6761-6767. DOI: 10.1021/jf800919u.

Pier A.C., Cabañes F.J., Chermette R., Ferreiro L., Guillot J., Jensen H.E., Santurio J.M. 2000. Prominent animal mycoses from various regions of the world. Medical Mycology 38 (1): 47-58. DOI: 10.1080/mmy.38.s1.47.58.

Pitt J.I. 2000. Toxigenic fungi and mycotoxins. British Medical Bulletin 56 (1): 184-192. DOI: 10.1258/0007142001902888

Polashock J.J., Hillman B.I. 1994. A small mitochondrial double-stranded (ds) RNA element associated with a hypovirulent strain of the chestnut blight fungus and ancestrally related to yeast cytoplasmic T and W dsRNAs. Proceedings of the National Academy of Sciences 91 (18): 8680-8684. DOI: 10.1073/pnas.91.18.8680.

Preisig O., Moleleki N., Smit W.A., Wingfield B.D., Wingfield M.J. 2000. A novel RNA mycovirus in a hypovirulent isolate of the plant pathogen Diaporthe ambigua. Journal of General Virology 81 (12): 3107-3114. DOI: 10.1099/0022-1317-81-12-3107. 
Preisig O., Wingfield B.D., Wingfield M.J. 1998. Coinfection of a fungal pathogen by two distinct double-stranded RNA viruses. Virology 252 (2): 399-406. DOI: 10.1006/viro.1998.9480.

Redecker D., Kodner R., Graham L.E. 2000. Glomalean fungi from the Ordovician. Science 289 (5486): 1920-1921. DOI: 10.1126/ science.289.5486.1920.

Rong R., Rao S., Scott S.W., Carner G.R., Tainter F.H. 2002. Complete sequence of the genome of two dsRNA viruses from Discula destructiva. Virus Research 90 (1-2): 217-224. DOI: 10.1016/S0168-1702(02)00178-8.

Saladin G., Magné C., Clément C. 2003. Effects of fludioxonil and pyrimethanil, two fungicides used against Botrytis cinerea, on carbohydrate physiology in Vitis vinifera L. Pest Management Science 59 (10): 1083-1092. DOI: 10.1002/ps.733.

Sande W.W.J., Lo-Ten-Foe J.R., Van Belkum A., Netea M.G., Kullberg B.J., Vonk A.G. 2010. Mycoviruses: future therapeutic agents of invasive fungal infections in humans? European Journal of Clinical Microbiology \& Infectious Diseases 29 (7): 755-763. DOI: 10.1007/s10096-010-0946-7.

Saracci R., Kogevinas M., Winkelmann R., Bertazzi P.A., De Mesquita B.B., Coggon D., Green L.M., Kauppinen T., L’abbé K.A., Littorin M., Lynge E., Mathews J.D., Neuberger M., Osman J., Pearce N. 1991. Cancer mortality in workers exposed to chlorophenoxy herbicides and chlorophenols. The Lancet 338 (8774): 1027-1032.

Sasaki A. 2009. Artificial infection of mycoviruses and their application. Bulletin of the National Institute of Fruit Tree Science 8: 1-14.

Sasaki A., Kanematsu S., Onoue M., Oyama Y., Yoshida K. 2006. Infection of Rosellinia necatrix with purified viral particles of a member of Partitiviridae (RnPV1-W8). Archives of Virology 151 (4): 697-707. DOI: 10.1007/s00705-005-0662-2.

Shah U.A., Kotta-Loizou I., Coutts R.H. 2015. Sequence determination of a satellite RNA isolated from Aspergillus foetidus. Archives of Virology 160 (3): 883-885. DOI: 10.1007/s00705-015-2338-x.

Shapira R., Choi G.H., Nuss D.L. 1991. Virus-like genetic organization and expression strategy for a double-stranded RNA genetic element associated with biological control of chestnut blight. The EMBO Journal 10 (4): 731-739. DOI: 10.1002/j.1460-2075.1991. tb08004.x.

Sinden J.W., Hauser E. 1950. Report on two new mushroom diseases. Mushroom Science 1: 96-100.

Singh R.P., Hodson D.P., Huerta-Espino J., Jin Y., Bhavani S., Njau P., Herrera-Foessel S., Singh P.K., Singh S., Govindan V. 2011. The emergence of Ug99 races of the stem rust fungus is a threat to world wheat production. Annual Review of Phytopathology 49: 465-481. DOI: 10.1146/annurev-phyto-072910-095423.

Smart C.D., Yuan W., Foglia R., Nuss D.L., Fulbright D.W., Hillman B.I. 1999. Cryphonectria hypovirus 3, a virus species in the family Hypoviridae with a single open reading frame. Virology 265 (1): 66-73. DOI: 10.1006/viro.1999.0039.

Son M., Yu J., Kim K.H. 2015. Five questions about mycoviruses. PLoS Pathogens 11 (11): e1005172. DOI: 10.1371/journal. ppat.1005172.

Strauss E.E., Lakshman D.K., Tavantzis S.M. 2000. Molecular characterization of the genome of a partitivirus from the basidiomycete Rhizoctonia solani. Journal of General Virology 81 (2): 549-555. DOI: 10.1099/0022-1317-81-2-549.

Sun L., Nuss D.L., Suzuki N. 2006. Synergism between a mycoreovirus and a hypovirus mediated by the papain-like protease p29 of the prototypic hypovirus CHV1-EP713. Journal of General Virology 87 (12): 3703-3714. DOI: 10.1099/vir.0.82213-0.

Supyani S., Hillman B.I., Suzuki N. 2007. Baculovirus expression of the 11 mycoreovirus-1 genome segments and identification of the guanylyltransferase-encoding segment. Journal of General Virology 88 (1): 342-350. DOI: 10.1099/vir.0.82318-0.

Suzaki K. 2006a. Helicobasidium mompa dsRNA virus N10. (Published at NCBI database).

Suzaki K. 2006b. L2-double stranded RNA in violet root rot fungus Helicobasidium mompa strain V670. (Published at NCBI database).

Tuomivirta T.T., Hantula J. 2003. Two unrelated double-stranded RNA molecule patterns in Gremmeniella abietina type A code for putative viruses of the families Totiviridae and Partitiviridae. Archives of Virology 148 (12): 2293-2305. DOI: 10.1007/s00705-0030194-6.

USDA (United States Department of Agriculture). Cereal Rusts. https://www.ars.usda.gov/midwest-area/st-paul-mn/cereal-disease-lab/ docs/cereal-rusts/cereal-rusts/ [dostęp: 07.06.2017].

USEPA (United States Environmental Protection Agency) 1992. Ethylene bisdithiocarbamates (EBDCs); notice of intent to cancel and conclusion of special review. Federal Register 57: 7484-7530.

Van Diepeningen A.D., Debets A.J., Hoekstra R.F. 1998. Intra- and interspecies virus transfer in Aspergilli via protoplast fusion. Fungal Genetics and Biology 25 (3): 171-180. DOI: 10.1006/fgbi.1998.1096.

Van Diepeningen A.D., Debets A.J.M., Slakhorst S.M., Fekete C., Hornok L., Hoekstra R.F. 2000. Interspecies virus transfer via protoplast fusions between Fusarium poae and black Aspergillus strains. Fungal Genetics Reports 47 (1): 99-100. DOI: 10.4148/19414765.1216.

Van Diepeningen A.D., Varga J., Hoekstra R.F., Debets A.J. 2008. Mycoviruses in aspergilla. s. 133-176. W: Aspergillus in the genomic era (J. Varga, R.A. Samson, red.). Wageningen Academic Publishers, Wageningen, The Netherlands, 334 ss. ISBN 978-90-8686065-4. DOI: 10.3920/978-90-8686-635-9.

Voth P.D., Mairura L., Lockhart B.E., May G. 2006. Phylogeography of Ustilago maydis virus H1 in the USA and Mexico. Journal of General Virology 87 (11): 3433-3441. DOI: 10.1099/vir.0.82149-0.

Walsh U.F., Morrissey J.P., O'gara F. 2001. Pseudomonas for biocontrol of phytopathogens: from functional genomics to commercial exploitation. Current Opinion in Biotechnology 12 (3): 289-295. DOI: 10.1016/S0958-1669(00)00212-3.

Wang L., Jiang J., Wang Y., Hong N., Zhang F., Xu W., Wang G. 2014. Hypovirulence of the phytopathogenic fungus Botryosphaeria dothidea: association with a coinfecting chrysovirus and a partitivirus. Journal of Virology 88 (13): 7517-7527. DOI: 10.1128/ JVI.00538-14.

Wei C.Z., Osaki H., Iwanami T., Matsumoto N., Ohtsu Y. 2003. Molecular characterization of dsRNA segments 2 and 5 and electron microscopy of a novel reovirus from a hypovirulent isolate, W370, of the plant pathogen Rosellinia necatrix. Journal of General Virology 84 (9): 2431-2437. DOI: 10.1099/vir.0.19098-0.

Whipps J.M., Sreenivasaprasad S., Muthumeenakshi S., Rogers C.W., Challen M.P. 2008. Use of Coniothyrium minitans as a biocontrol agent and some molecular aspects of sclerotial mycoparasitism. European Journal of Plant Pathology 121 (3): 323-330. DOI: 10.1007/ s10658-007-9238-1.

Wiebols I.G., Wieringa I.K. 1936. Bacteriophagie een algemeen voorkomend verschijnsel. H. Veenman und Zonen, Wageningen.

Wood H.A., Bozarth R.F. 1973. Heterokaryon transfer of viruslike particles and a cytoplasmically inherited determinant in Ustilago maydis. Phytopathology 63: 1019-1021. 
Xie J., Wei D., Jiang D., Fu Y., Li G., Ghabrial S., Peng Y. 2006. Characterization of debilitation-associated mycovirus infecting the plantpathogenic fungus Sclerotinia sclerotiorum. Journal of General Virology 87 (1): 241-249. DOI: 10.1099/vir.0.81522-0.

Yaegashi H., Nakamura H., Sawahata T., Sasaki A., Iwanami Y., Ito T., Kanematsu S. 2013. Appearance of mycovirus-like double-stranded RNAs in the white root rot fungus, Rosellinia necatrix, in an apple orchard. FEMS Microbiology Ecology 83 (1): 49-62. DOI: 10.1111/j.1574-6941.2012.01454.x.

Yokoi T., Takemoto Y., Suzuki M., Yamashita S., Hibi T. 1999. The nucleotide sequence and genome organization of Sclerophthora macrospora virus B. Virology 264 (2): 344-349. DOI: 10.1006/viro.1999.0018.

Yokoi T., Yamashita S., Hibi T. 2003. The nucleotide sequence and genome organization of Sclerophthora macrospora virus A. Virology 311 (2): 394-399. DOI: 10.1016/S0042-6822(03)00183-1.

Yokoi T., Yamashita S., Hibi T. 2007. The nucleotide sequence and genome organization of Magnaporthe oryzae virus 1. Archives of Virology 152 (12): 2265-2269. DOI: 10.1007/s00705-007-1045-7.

Yu J., Kwon S.J., Lee K.M., Son M., Kim K.H. 2009. Complete nucleotide sequence of double-stranded RNA viruses from Fusarium graminearum strain DK3. Archives of Virology 154 (11): 1855-1858. DOI: 10.1007/s00705-009-0507-5.

Yu X., Li B., Fu Y., Jiang D., Ghabrial S.A., Li G., Peng Y., Xie J., Cheng J., Huang J., Yi X. 2010. A geminivirus-related DNA mycovirus that confers hypovirulence to a plant pathogenic fungus. Proceedings of the National Academy of Sciences 107 (18): 8387-8392. DOI: 10.1073/pnas.0913535107.

Yu X., Li B., Fu Y., Xie J., Cheng J., Ghabrial S.A., Li G., Yi X., Jiang D. 2013. Extracellular transmission of a DNA mycovirus and its use as a natural fungicide. Proceedings of the National Academy of Sciences 110 (4): 1452-1457. DOI: 10.1073/pnas.1213755110.

Zhang R., Hisano S., Tani A., Kondo H., Kanematsu S., Suzuki N. 2016. A capsidless ssRNA virus hosted by an unrelated dsRNA virus. Nature Microbiology 1: 15001. DOI: 10.1038/nmicrobiol.2015.1.

Zhang T., Jiang Y., Huang J., Dong W. 2013. Genomic organization of a novel partitivirus from the phytopathogenic fungus Ustilaginoidea virens. Archives of Virology 158 (11): 2415-2419. DOI: 10.1007/s00705-013-1742-3. 